\title{
Making Intangibles Tangible: Identifying Manifestations of Cultural Ecosystem Services in a Cultural Landscape
}

\author{
Wei Jiang ${ }^{1, *(1)}$ and Rainer Marggraf ${ }^{2}$ \\ 1 State Key Laboratory of Urban and Regional Ecology, Research Center for Eco-Environmental Sciences, \\ Chinese Academy of Sciences, Beijing 100085, China \\ 2 Department of Agricultural Economics and Rural Development, Georg-August-University Göttingen, \\ 37073 Gottingen, Germany; rmarggr@uni-goettingen.de \\ * Correspondence: weijiang@rcees.ac.cn
}

Citation: Jiang, W.; Marggraf, R. Making Intangibles Tangible: Identifying Manifestations of Cultural Ecosystem Services in a Cultural Landscape. Land 2022, 11, 26. https:// doi.org/10.3390/land11010026

Academic Editor: Joerg Priess

Received: 29 November 2021

Accepted: 22 December 2021

Published: 24 December 2021

Publisher's Note: MDPI stays neutral with regard to jurisdictional claims in published maps and institutional affiliations.

Copyright: (c) 2021 by the authors Licensee MDPI, Basel, Switzerland. This article is an open access article distributed under the terms and conditions of the Creative Commons Attribution (CC BY) license (https:// creativecommons.org/licenses/by/ $4.0 /)$.

\begin{abstract}
The assessment of cultural ecosystem services (CES) has proved challenging due to their intangible, non-material and invisible characteristics. A number of methods for evaluating CES have been developed, which depend mostly on subjective perceptions and behavior. An objective direction for considering CES is proposed based on the assumption that making use of CES leaves visible manifestations in the physical landscape and human society. The approach developed in this paper attempts to follow this direction by identifying a large amount of manifestations that reflect a wider range of CES types. This approach is applied to a case study of the Weser River in Germany, showing that the local people along the river have benefited from multiple CES of the Weser and created various manifestations of those CES. In the future researches, the identification and documentation of manifestations can be used to map the delivery of CES, to develop indicator systems for CES, to assess heritage value and identity, to indicate spatially explicit preferences on ecosystem characteristics and visual aesthetic qualities, to estimate the economic value of educational and inspirational service, to investigate sense of place, as well as to make better informed landscape management and nature protection.
\end{abstract}

Keywords: cultural ecosystem services; river ecosystem; manifestations identification; human-nature interactions; Germany

\section{Introduction}

Cultural ecosystem services (CES) are defined as the non-material benefits people obtain from ecosystems through spiritual enrichment, cognitive development, reflection, recreation, and aesthetic experience [1]. Like all other ecosystem services, CES must demonstrate a certain relationship between ecosystems in the biophysical domain and human needs in the social domain, although some CES may have little dependence on ecosystems (Daniel et al., 2012). As ecosystems cannot deliver benefits to people by themselves without incorporating social inputs like human capital and built capital, CES may depend on human and built capital to a greater degree [2].

Although studies on CES are still confronted with intangible, non-material and invisible challenges, a number of evaluation methods that employ different procedures, start from different theoretical backgrounds and apply different techniques are identified [3]. These methods are divided into two main categories, monetary methods and non-monetary methods. The monetary methods category involves revealed preference, including market price method [4], travel cost method [5], and hedonic pricing method [6], and stated preference, including deliberative valuation method [7], contingent valuation method [8], and choice experiment method [9]. The non-monetary methods category can also be classified into revealed preference, including observation method [10], document method [11], social media-based method [12], and stated preference, including interview method [13], questionnaire method [14], narrative method [15], focus group method [16], 
expert based method [17], Q-method [18], participatory mapping method [19], participatory GIS method [20], and public participation GIS method [21]. To a large extent, these methods depend generally on subjective perceptions, behavior or responses of participants such as tourists, stakeholders, aboriginal peoples, local residents or experts.

Human cultures are always influenced and shaped by natural landscapes, while humans always influence and shape their surrounding environment to enhance the availability of these services [22]. Indigenous peoples and local communities play an essential role in this reciprocal process, not only by maintaining, enhancing and managing ecosystems [23,24] and effectively conserving biodiversity [25] based on their knowledges, skills and capabilities [26], by incorporating their livelihood, well-being and value perceptions into policy-making [27] and building connections with ecosystems [28], but also by generating cultural landscapes and delivering CES [29,30].

This reciprocal relationship leads to the assumption that making use of CES leaves discernible marks in the physical landscape and human society [31]. Based on this assumption, an objective method has been developed by a series of studies. Bieling and Plieninger proposed an approach for analyzing correlations between visible manifestations of CES in a field walk-based landscape and ecosystem service bundles [31]. Coscieme focused on popular music that reflects the inspirational service of multiple ecosystems and estimated the inspirational value [32]. Figueroa-Alfaro and Tang used geo-tagged photographs from social media to identify aesthetic value in non-monetary terms [33]. Hutcheson et al. considered educational programs as the educational service provided by the Hudson River and estimated the economic value of this educational service based on the travel cost method [34]. Hiron et al. considered poetry as the results of the inspirational service provided by bird species [35]. Katayama and Baba showed that Japanese children's songs reflect the inspirational service and measured the inspirational value [36]. Additionally, Jiang and Marggraf suggested that the inspirational service is also reflected by published books [37].

The valuable services provided by river ecosystems such as wildlife habitat, electric power and transportation have been recognized since the 1990s [38]. The constant flow of rivers is often associated with the irreversible passing of time or the conformity of society [32]. Hence, in this paper, we focus on river ecosystems and attempt to identify more manifestations in the physical landscape or human society that reflect a wider range of CES provided by rivers. For this purpose, we develop an approach, termed as making intangibles tangible, for identifying different kinds of manifestations that reflect multiple CES. We then apply this approach to a case study of the Weser River in Germany, showing the manifestations of CES provided by the river.

\section{Methods and Materials}

\subsection{Approach}

The approach we develop consists of three steps: First, choose a spatially clearly defined ecosystem and present the history of interactions between local people and this ecosystem. The assumption behind is that the longer people interact with their surrounding ecosystems, the more manifestations that reflect CES can be found.

Second, identify potential manifestations of each CES category relevant to the ecosystem. Based on the Common International Classification of Ecosystem Services (CICES) [39], three groups of CES with eight classes are taken into account. The scientific and educational classes are merged due to their close relatedness. The description of the aesthetic class, artistic representations of nature, is associated with the inspirational service, thus we use the term inspirational instead of aesthetic to avoid the confusion with the terms used in Millennium Ecosystem Assessment (MA). Furthermore, in order to keep consistent, we insist on using the noun forms of terms for all classes such as science and education, inspiration, symbol, sacredness and religiousness (Table 1). 
Table 1. The classification of CES (modified from CICES V5.1).

\begin{tabular}{cl}
\hline \multicolumn{1}{c}{ Group } & \multicolumn{1}{c}{ Class } \\
\hline \multirow{2}{*}{ Physical and experiential interactions } & $\begin{array}{l}\text { Physical use of land- or seascapes } \\
\text { Experiential use of land- or seascapes }\end{array}$ \\
\hline \multirow{3}{*}{ Intellectual and representative interactions } & $\begin{array}{l}\text { Science and education } \\
\text { Cultural Heritage } \\
\end{array}$ \\
& $\begin{array}{c}\text { Entertainment } \\
\text { Inspiration }\end{array}$ \\
\hline \multirow{2}{*}{ Spiritual and emblematic interactions } & Symbol \\
& Sacredness and religiousness \\
\hline
\end{tabular}

Third, search for concrete manifestations of each CES class. We adopt the so-called snowball strategy, that is, a small number of fundamental studies will lead to a large number of relevant studies according to their references and citations [37]. For our case study, based on two publications, "Die Weser: vom Thüringer Wald bis zur Nordsee" [40] and "Die Weser: 1800-2000" [41], more information about the Weser has been found, which includes field studies, digital maps, remote sensing data, publications from multiple disciplines, and gray literature from internet.

\subsection{Study Area}

The Weser River is the only large river that lies entirely within German national territory. It forms at Hannoversch Münden by the confluence of the rivers Werra and Fulda, flows in the northern direction through the Central Upland Ranges and the North German Plain, and empties into the North Sea, having an overall length of $453 \mathrm{~km}$. Currently, there are around 1.5 million residents living directly along the Weser River, distributing in 66 municipalities in 16 districts of four federal states (Figure 1).

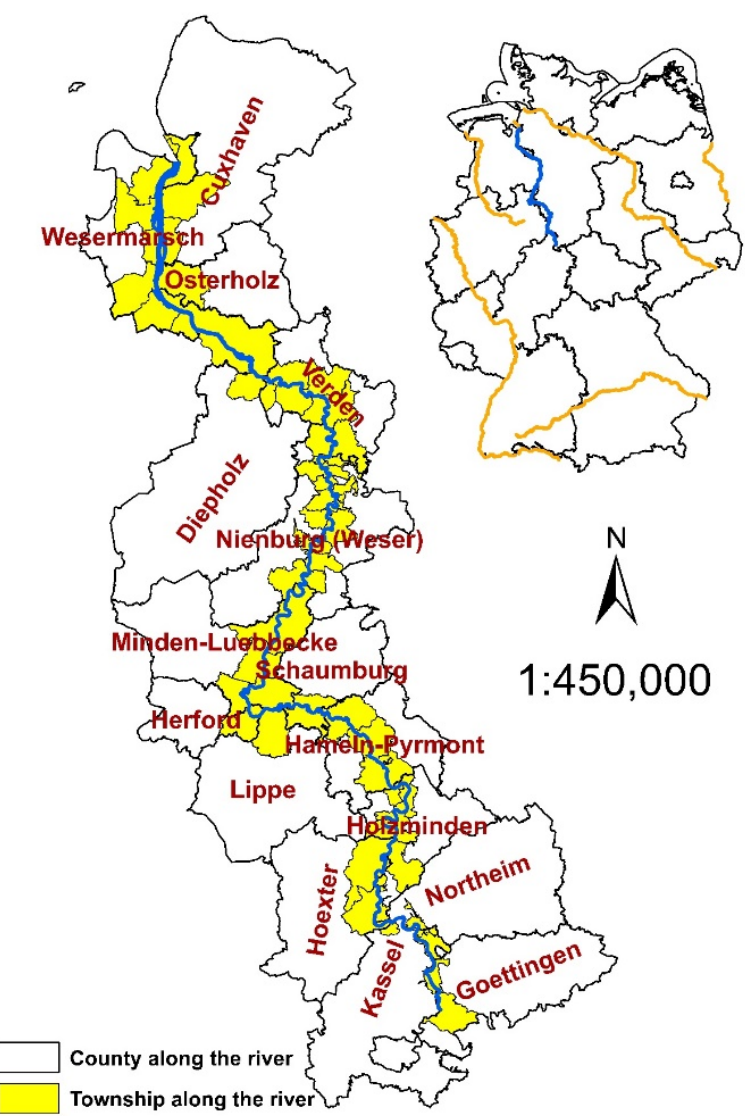

Figure 1. The geographical location of the Weser River in Germany. 


\section{Case Study}

\subsection{A Brief History about Human Activities around the Weser}

The history of human activities along the Weser can be dated back to the first four centuries, which is confirmed by the findings in the riverbed or on the banks. The Weser region began substantial development since Charlemagne conquered this region, when a number of important settlements, such as Münden, Hameln, Höxter, Minden, Nienburg and Bremen, arose by reason of military or ecclesial relevance. This river was given the name Weser in the eighth century [42,43].

In the long historical period, the Weser has been deemed an important lifeline. It provides not only food (fish), but also drinking and processing water to local people. Meanwhile, the river is the only transportation route. For the sake of better navigability, local people has begun early to reconstruct and improve the waterway by means of hydroengineering interventions. The river has also served as wastewater disposal. The water quality of the Weser deteriorates with the increasing industrialization and population growth and has been gradually improved through the construction and expansion of municipal and industrial wastewater treatment plants and the reduction of salt discharges from the potash industry in the last decades. Furthermore, the river plays an outstanding role for recreational activities due to its diversified and attractive landscape. On the dark side, the terrifying and destructive effects of floods also accompany the history of local people along the Weser [42,43]. All of these facts indicate that the interactions between local people and the river are very intensive, implying that there exist plentiful manifestations that reflect the CES provided by the river to local people.

\subsection{Identifying Potential Manifestations}

Based on the CES classification described in Table 1, we identify the potential manifestations relevant to river ecosystems for each CES class (Table 2). Considering the difficulty in relating intangible services to ecosystem elements or functions [44], we interpret the relationships between ecosystem features and the respective manifestations.

Table 2. Potential manifestations relevant to river ecosystems for each CES class.

\begin{tabular}{|c|c|c|}
\hline Group & Class & Manifestation \\
\hline \multirow{2}{*}{ Physical and experiential interactions } & Physical use of land- or seascapes & $\begin{array}{l}\text { Swimming areas, landing stages, camping sites, } \\
\text { cycle routes }\end{array}$ \\
\hline & Experiential use of land- or seascapes & Viewing points \\
\hline \multirow{4}{*}{ Intellectual and representative interactions } & Science and education & Museums \\
\hline & Cultural Heritage & Bridges, tunnels, ferries, canals, harbors, \\
\hline & Entertainment & $\begin{array}{l}\text { Darrages, alkes } \\
\text { Photographs }\end{array}$ \\
\hline & Inspiration & Legends, poems, proses, novels, paintings \\
\hline \multirow[b]{2}{*}{ Spiritual and emblematic interactions } & Symbol & Coats of arms \\
\hline & Sacredness and religiousness & $\begin{array}{l}\text { The whole or a part of the river, plants or animals } \\
\text { living in the river }\end{array}$ \\
\hline
\end{tabular}

\subsubsection{Physical and Experiential Use}

Ecosystems are often attractive places where people can engage in some form of naturebased recreational and experiential activities, which in turn provide an opportunity for people to obtain directly the benefits of ecosystem services. Physical activities in, on or along a river include swimming, boating, biking, and camping, while the major in situ experiential activity related to a river is scenery viewing. Since these activities depend usually on built infrastructure and accessibility, the constructive objects like swimming areas, landing stages, cycle routes, camping sites and viewing points are chosen as the manifestations of both classes. The close relationship between ecosystems and infrastructures for physical or experiential use consists in that the degradation or improvement of ecosystem quality would lead to corresponding negative or positive changes in visitor number to and use frequency of these infrastructures. 


\subsubsection{Science and Education}

Generally speaking, ecosystems exist longer than humankind. In the long period of time, ecosystems have recorded the evolutionary traces of the earth and witnessed the human history. Hence, people can learn the knowledge about their natural environment and obtain the information about their own history from them, which can be seen as the scientific and educational service of ecosystems. Permanent objects, rather than temporary research programs or guided tours devoted to river ecosystems are taken into account. Since the primary purpose of modern museums is to collect, conserve, research, exhibit, and interpret objects of art, natural history, science, technology, or human history [45], they are appropriate manifestations for scientific and educational services. Despite the lag of time, any significant change in ecosystem features would be collected and recorded in museums.

\subsubsection{Cultural Heritage}

Cultural heritage is conceptualized as memories associated with specific ecosystem features from past cultural connections that remind people of their collective and individual roots [46], implying the inextricable long-term interactions between human influences and ecosystem features. Following the definition by United Nations Educational, Scientific and Cultural Organization, cultural heritage are monuments, groups of buildings and sites that are built up by past generations, maintained in the present, and bestowed on future generations [47]. Rivers in the pre-modern times were generally deemed geographical barriers to be crossed, the most effective natural transportation ways before trains, automobiles and airplanes are invented, and potential risks for nearby settlements owing to floods. The interactions between rivers and people living around them are accordingly represented by connecting both banks of rivers (bridges, tunnels, and ferries), by improving and modifying waterways for navigation (canals and harbors), and by altering water flows for flood prevention (barrages and dikes). The stone bridge on the Danube in the old town of Regensburg is an example of world cultural heritage. We must keep in mind that heritages are not only inherited from the past but also face the future. Managed or even heavily altered ecosystems can acquire cultural significance over time [48]. Rivers were and are still deemed barriers, transportation ways, and risks, those infrastructures reflect the very interactions how people and rivers coexist for a long time. If bridges or dikes were no more necessary in the future, they would become heritages that reflect our culture at the present.

\subsubsection{Entertainment and Inspiration}

Ecosystems inspire an almost unlimited array of representations in art, writings, etc., which consciously or subconsciously remind us of our ties with nature and shape our views and appreciation of the represented ecosystems. MA distinguishes five categories of inspirational service: verbal arts (legends, poems, fictions, etc.), performing arts (music, songs, dance, etc.), fine arts (paintings, sculptures, crafts, etc.), designs and fashion (home furnishings, clothing, etc.), and media (radios, televisions, films, advertisings, websites, etc.) [22]. CICES identifies the class of inspiration as artistic representations of nature, and an additional class of entertainment as ex situ viewing of nature through social media, in contrast to in situ experience and activities [39]. Both classes are derived from the same service type in MA, but the most important difference between them is that entertainment refers to ex situ experience of nature, while inspiration refers to mental stimulation and creative work based on in situ experience of nature. Since entertainment can also be provided by artistic representations of nature, the distinction between them should be made that only materials produced and shared by the general public like travel notes, short video, or photographs are considered as manifestations for entertainment, while materials created by professionals or artists like poems, songs, paintings or films are deemed manifestations for inspiration. Worldwide reputable examples about rivers include "The Blue Danube" by Johann Strauss II and "And Quiet Flows the Don" by Mikhail Sholokhov. 
Although entertainment relates to ecosystems only in a very indirect way, while inspiration depends strongly on ecosystem features, changes in ecosystems would affect both of them. For instance, viewing a river with clean blue water, either in situ or ex situ, is much more inspiring and entertaining than viewing one with dirty polluted water.

\subsubsection{Symbol}

The relationship between ecosystem features and the symbolic service is straightforward. Since municipal coats of arms often have representative symbols of plants, animals or ecosystems, e.g., the common rue of Saxony, the bear of Berlin, or the Rhine of North Rhine-Westphalia, they are appropriate manifestations of this service.

\subsubsection{Sacredness and Religiousness}

People often search for spiritual connections to their environment through personal reflections, organized rituals or traditional taboos, while ecosystems or species provide an important medium for this orientation in time and space [22]. Reasonably, the whole river, a certain part of the river, or certain species living in the river can serve as the manifestations of holy places or sacred plants and animals.

\subsection{Searching for Concrete Manifestations \\ 3.3.1. Physical Use}

A variety of recreational activities are available in, on or along the Weser. Twelve swimming areas are located in the downstream of the river due to wider surface and better water quality, 126 loading stages for boating and cruise are found in almost every village, town and city, 48 camping sites are often combined with other possibilities like fishing and boating, and the Weser Cycle Route from Hannoversch Münden to Bremerhaven with the length of $515 \mathrm{~km}$ belongs to the most attractive cycle routes in Germany [49].

\subsubsection{Experiential Use}

Viewing points can be part of a building (e.g., a tower) or be built in the natural topography (e.g., on a hilltop). A total of 74 viewing points are found along the Weser. Typical forms in the upstream are constructions on the hills, such as the Monument of Weser Song in Hannoversch Münden, the Skywalk of Hannoversche Cliff in Bad Karlshafen, and the Monument of Kaiser Wilhelm in Porta Westfalica, while typical examples in the downstream are the observation tower in Lemwerder, the lighthouse and the water tower in Bremen [50].

\subsubsection{Science and Education}

There are two museums relevant to the Weser River. One is the Weser Renaissance Museum at Brake Castle. This museum collects the materials and delivers the knowledge about the Weser Renaissance, which is a form of architectural style that is found in the area around the Weser in the period between the Reformation and the Thirty Years War. The Weser played a significant role for idea communication and information exchange through traveling of merchants, artists, and scholars [51]. The other is the German Fairy-tales and Weser Legends Museum located in Bad Oeynhausen, which illustrates the history of collection and writing of fairy-tales and legends about the Weser.

\subsubsection{Cultural Heritage}

There are totally 55 bridges, 23 ferries and one tunnel across the Weser. The bridges over the Weser cover almost all structure types, such as beam bridge, arch bridge, and suspension bridge, and they are used to carry pedestrians, trains or road traffic. The ferries on the Weser that are privately managed serve as the supplement to bridges. The only tunnel across the Weser was constructed from 1998 to 2004 for offering a connection between Nordenham and Bremerhaven. A total of 35 harbors are distributed in the cities and towns along the Weser, among which the most important and largest ones are located in 
Bremen and Bremerhaven. The middle course of the Weser is regulated by seven barrages built in the 20th century. Accordingly, seven canals that shorten the shipping distance were constructed for the purpose of navigation. Furthermore, $353 \mathrm{~km}$ dikes are built for flood prevention in the lower course of the Weser.

\subsubsection{Entertainment}

Since a huge amount of geo-tagged photographs relevant to the Weser is found on Google Maps, three photos in high quality are chosen from three typical viewing points along the Weser, the Monument of Weser Song in Hannoversch Münden, the Skywalk of Hannoversche Cliff in Bad Karlshafen, and the Monument of Kaiser Wilhelm in Porta Westfalica (Table 3). These photos show a part of the Weser and indirectly share the beauty of this river.

Table 3. The entertainment service represented by selected photographs about the Weser (based on Google Maps).

The Monument of Weser Song in Hannoversch Münden

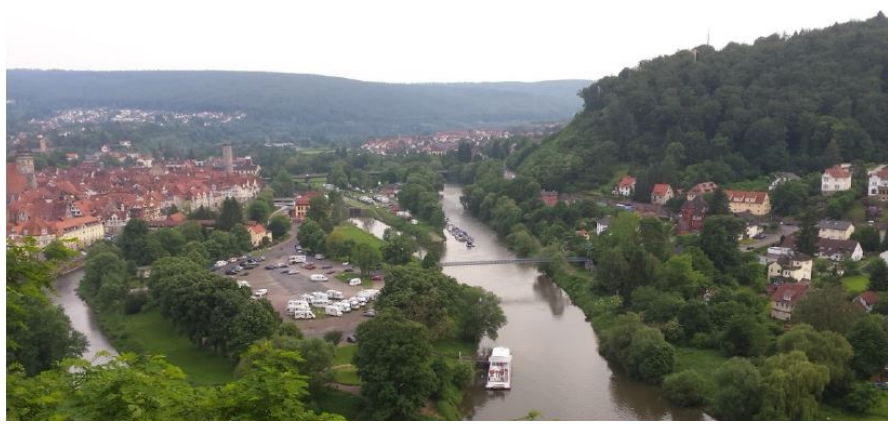

The Skywalk of Hannoversche Cliff in Bad Karlshafen
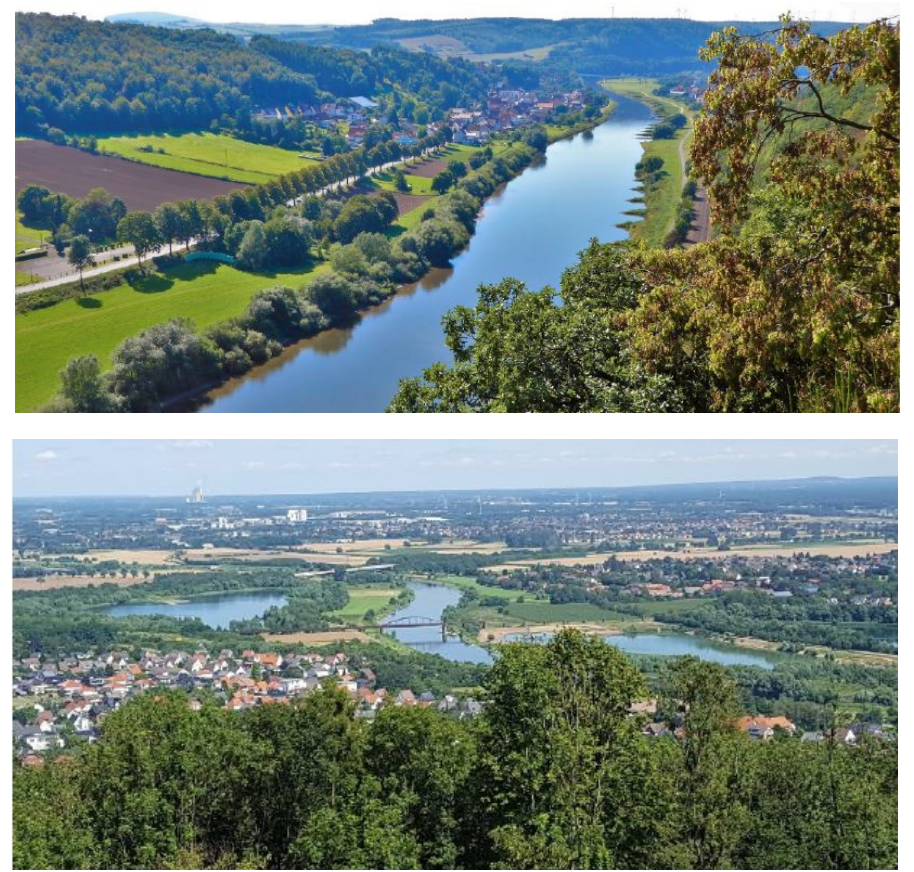

The Monument of Kaiser Wilhelm in Porta Westfalica

\subsubsection{Inspiration}

The Weser is generally not the leading character, but often plays a non-negligible role in the German folklores [52] (Table 4). Clearly, the images of the floating ice sheets or the drifting shell are closely associated with the river, implying that they cannot be imagined in a story if the river would not exist. The story about the Westphalian Gorge is related to the geomorphological features, which indicates an impressive description of a possible 
event in the natural history of the river [42]. The folklore about the dike in Bremen gives us a wonderful example of the interaction between people and flood.

Table 4. The inspiration service represented by folklores about the Weser (translated from [52]).

\begin{tabular}{cl}
\hline Place & Folklore \\
Grohnde & $\begin{array}{l}\text { When the Trumpeter stepped from the warm room } \\
\text { into the bright moonlight, he felt as if a mild wind was } \\
\text { blowing. Or should that only be his heated blood? He } \\
\text { hurried through the streets, came to the towpath, and } \\
\text { looked over the Weser. A light flashed on the other } \\
\text { side in Grohnde. Ah, in the hours of merriment, the } \\
\text { Weser had come to life again. The thawing wind had } \\
\text { licked the ice cover; the urgent flow had broken it into } \\
\text { large slabs and driven the ambulant mass crashing to } \\
\text { the North Sea. }\end{array}$ \\
\end{tabular}

Because lightning came down, split the mountain with terrible thunderclap and opened a gaping ravine, through which the water could flow out again like the

Porta Westfalica How did the Westphalian Gorge arise smoke in the chimney. Slowly the hills rose from the floods again like islands, the fields and houses emerged, and the Weser returned to its bed. But its water flowed henceforth northward through the new notch, and thus the Westphalian Gorge arose.

A shepherd was grazing his herd on a green meadow near the Weser between Petershagen and Windheim. The sun sank and the moon came up with its stars, Petershagen The shepherd of Petershagen and the shepherd was still sitting on the bank hill by the river. There he was watching something on the river, floating closer, light as a feather in the wind. And shortly he saw a figure in the moonlight standing there on a drifting shell in the water.

As the gnawing water continued to rise and the whole protective wall was in danger, the guards let the bells of all towers ring. There ran the crowds of Bremers, men, women, children, and saw the whole mess: a large hole was torn in the dike. The surge forced itself into the rift and washed away the edges. The wild waves weltered already gurgling, moaning against the Bremen How was the Theisenrad Dike saved houses. In vain the workmen plunge the whole truckloads of timber, soil, stones, and junk into the gaping hole. The torrential floods carried away everything, and the misfortune became only worse. In this emergency, Bremers recalled the old promise, and a terrible word got around. First quiet, then louder people grumbled: "A person must in the Wall, or we all sink. Hey, councilors, give us the victim!"

A number of literary works in different genres such as poems, proses and novels are created by many writers (Table 5). The poem on the Weser Stone in Hannoversch Münden was written by Carl Natemann who emphasized the formation of the river through the convergence ("kiss") of two rivers Werra and Fulda [40]. The prose written by von Dingelstedt describes his view of mountains, villages and water when traveling on a boat [53]. Additionally, Raabe meticulously delineated a garden near the river and the stars reflected in the Weser that was like a mirror [54]. 
Table 5. The inspiration service represented by literature works about the Weser.

\begin{tabular}{|c|c|c|}
\hline Place & Genre & Excerpt \\
\hline Hannoversch Münden & Poem & $\begin{array}{l}\text { Where Werra and Fulda kiss } \\
\text { They must atone their names, } \\
\text { And here begins by this kiss } \\
\text { German up to the sea the Weser River [40]. }\end{array}$ \\
\hline The whole river & Prose & $\begin{array}{l}\ldots, \text { where the Weser flows, mid through beautiful, though not large } \\
\text { mountains, over friendly, but not rich villages, without steamships } \\
\text { and without three-master, but often fraught with an ark hanging a } \\
\text { colorful pennant, on which blithe people sit and look out or sing out } \\
\text { over the blue water toward the blue mountains [53]. }\end{array}$ \\
\hline Holzminden & Novel & $\begin{array}{l}\text { The young, just flowering leaf buds of the low shrubs are hung with } \\
\text { dewdrops. Some early white and yellow flowers shine weakly from } \\
\text { the beds in the dusky night. The old river rustles and grumbles under } \\
\text { the wall of the garden. Leaning on the parapet against the river, the } \\
\text { Monika Fichtner stands and looks out dreamily shyly over the mirror } \\
\text { of the Weser, in which the stars and the great comet contemplate their } \\
\text { a thousand times reflected the image [54]. }\end{array}$ \\
\hline
\end{tabular}

The Weser also inspires the creative desire of painters (Figure 2). Wilhelm Strack faithfully and vividly represented the central role of the Weser in the city of Hameln, the scene of the landscape at the Westphalian Gorge, and the panorama of the Weser Valley [55], while the view of the Weser Valley [56] and the personification of the Weser [57] are beautiful imagination of the river.

Besides, there are two songs related to the Weser, one is "The Weser song", the other is "Where the Weser makes a big bow" (also known as "The Weser Bow song"), and a TV program "The Weser" produced by Northern German Broadcasting. These videos can be found on YouTube.

\subsubsection{Symbol}

The municipal coats of arms of all 16 districts, eight collective municipalities and 66 municipalities along the Weser are examined. We illustrate some coats of arms that symbolize the Weser in Figure 3. According to the official interpretations, all of the wavy shapes stand for the Weser [58,59], regardless of their locations (middle or bottom), orientations (horizontal, vertical or diagonal), colors (golden, silver, blue or red), or different patterns. A simple statistic shows that four districts (25\%), five collective municipalities $(63 \%)$ and 28 municipalities $(42 \%)$ have symbols of the Weser on their coats of arms. Since the acceptance or change of coats of arms is decided by local communities and special importance is placed consciously on home awareness in the design of coats of arms [60], they actually reflect the sense of place provided by the Weser River.

\subsubsection{Sacredness and Religiousness}

In comparison with the religious significance of the river Ganga to Hindus, the Tano River to Asante, the Nile perch to the ancient Egyptians, or the Amazonian dolphin to the most native tribes [61], no evidences are found to indicate that the Weser and the species living in it have any sacred or religious meaning to the local Germans. 


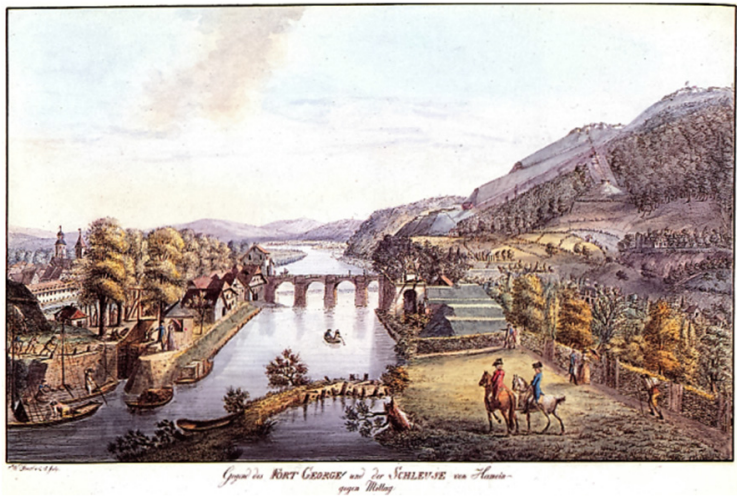

The fort and the lock of Hameln about noon, 1790

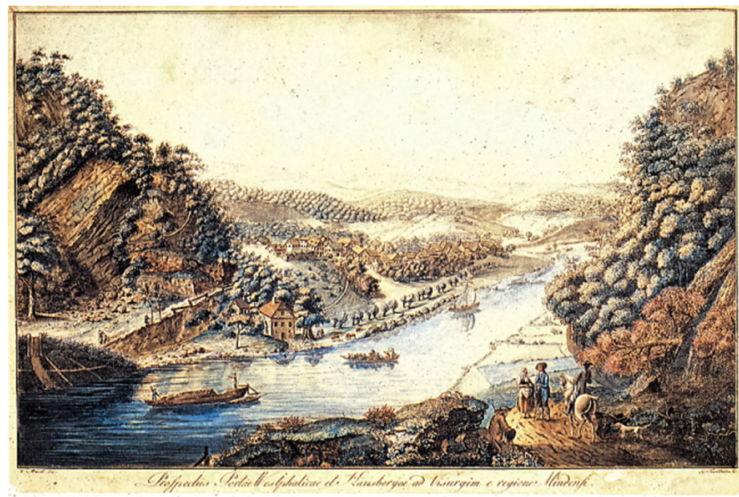

The Westphalian Gorge and Haus Hill to the south, 1786

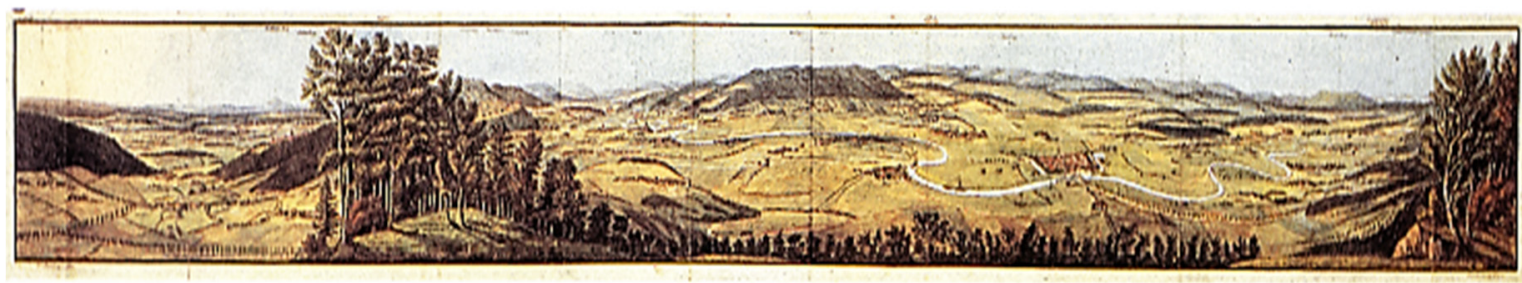

Panorama of the Weser Valley from the Luhden Cliff, 1823

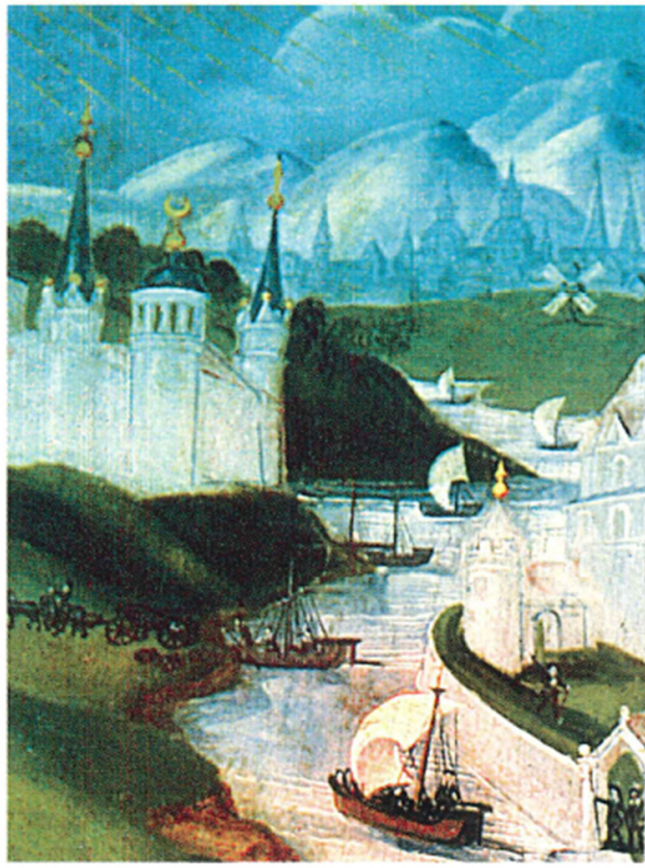

View of the Weser Valley, 1610

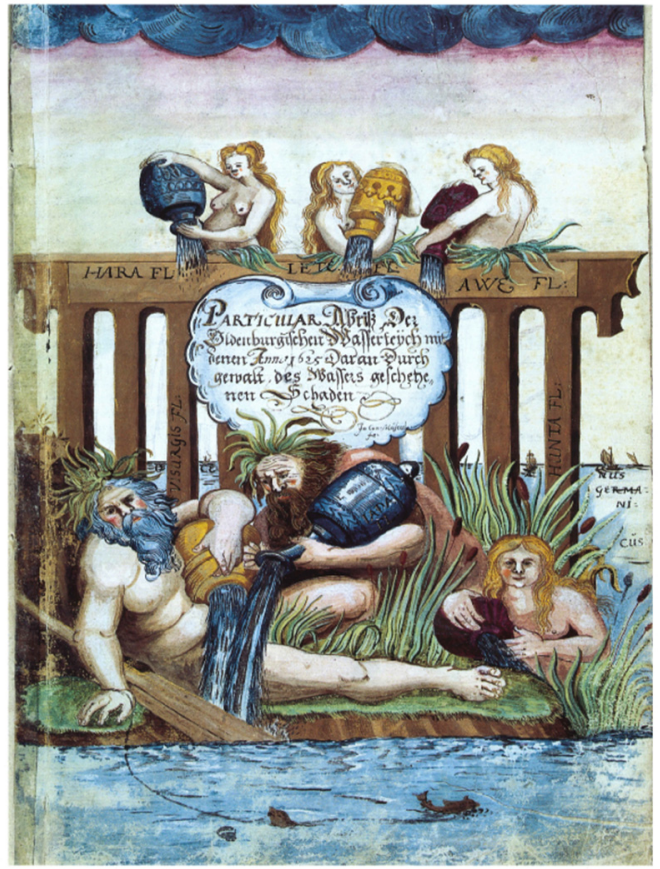

Personification of the Weser, 1625

Figure 2. The inspiration service represented by paintings about the Weser. 


\begin{tabular}{|c|c|c|c|c|}
\hline & Blende & Bevern & Rinteln & Boffzen \\
\hline Höxter & Betershagen & Berne & Emmerthal & \begin{tabular}{c} 
Bodewerder \\
\hline
\end{tabular} \\
\hline
\end{tabular}

Figure 3. The symbol service represented by municipal coats of arms.

\section{Discussion}

\subsection{Limitations and Advantages of This Approach}

Due to the data availability and the overwhelming amount of data sources, the inventory of manifestations that reflect CES of the Weser is far from being exhaustive in two senses. First, a large number of photographs on Google Maps, more paintings [53,62], and potential literature works that we did not find are not involved. Second, many relevant manifestations in association with CES are not considered, such as leisure fishing as a recreational activity, research papers, monographs and textbooks for the scientific and educational service, and logos of companies, institutes and other organizations for the symbolic service. This fact implies that the application of this approach at a larger scale (e.g., at national or global scale) is challenging, if not impossible.

On the other hand, the advantages are also obvious. First, this approach can be easily applied to other ecosystem types such as forests, grasslands, lakes, etc., by choosing an appropriate set of potential manifestations. Second, since measurement or valuation of CES often suffers from the issue of overlap and interconnectedness [63], using clearly defined manifestations contributes to avoiding double-counting. We take an extreme example to explain this: A documentary film director was inspired by the beauty and historical heritages when she was hunting in a forest. She took a lot of photos of the forest and produced a film later in order to share her experience, provide entertainment, and convey some knowledge about the forest to her audience. The question is which service the forest delivered to the director and the audience. By focusing on the output (film), we identify the inspirational service of the forest to the director, while the physical use service (hunting), the experiential use service (beauty), cultural heritage and educational service of this forest should be reflected by other manifestations. The photos taken by the director represent the entertainment service of the forest to her audience.

\subsection{Implications for Future Research}

First of all, the identification of manifestations plays an important role in mapping the delivery of CES [64] and developing indicator systems for CES [65]. Furthermore, documenting manifestations can be used for further analysis of CES. For example, manifestations of cultural heritage is useful for the assessment of heritage value and identity [66,67]; photographs indicate spatially explicit preferences and priorities on ecosystem characteristics [68] and visual aesthetic qualities and attractiveness [69]; educational programs are used to estimate the economic value of educational service [34]; music [32], songs [36], poetry [35] and published books [37] reveal the value of inspirational service; coats of arms are potential for investigating sense of place, which has been investigated through the lens of language [70]. Last but not least, manifestations of CES enable better informed landscape management and planning [71] and nature protection [72]. 


\section{Conclusions}

The frequently used methods for the assessment of CES depend significantly on the subjective perceptions, actions and responses of participants. Another objective direction for considering CES is developed based on the assumption that making use of CES leaves visible manifestations in the physical landscape and human society. The approach developed in this paper contributes to the objective direction by illustrating a large amount of manifestations that reflect a wider range of CES types. This approach is applied to a case study of the Weser River in Germany, showing that the local people along the river have benefited from multiple CES of the Weser and created various manifestations of those CES. This approach can be easily applied to other specific ecosystems over the world. In the future researches, the identification and documentation of manifestations can be used to map the delivery of CES, to develop indicator systems for CES, to assess heritage value and identity, to indicate spatially explicit preferences on ecosystem characteristics and visual aesthetic qualities, to estimate the economic value of educational and inspirational service, to investigate sense of place, as well as to make better informed landscape management and nature protection.

Author Contributions: Conceptualization, W.J.; methodology, W.J.; data curation, W.J.; writingoriginal draft preparation, W.J.; writing-review and editing, W.J.; supervision, R.M. All authors have read and agreed to the published version of the manuscript.

Funding: This work was funded by National Key Research and Development Program of China (No. 2017YFA0604701)

Acknowledgments: We would like to appreciate the supporting efforts made by Jiamei Xiao.

Conflicts of Interest: The authors declare no conflict of interest.

\section{References}

1. TEEB. Mainstreaming the Economics of Nature: A Synthesis of the Approach, Conclusions and Recommendations of TEEB. 2010. Available online: http:/ / teebweb.org/publications/teeb-for/synthesis/ (accessed on 15 December 2021).

2. Costanza, R.; De Groot, R.; Braat, L.; Kubiszewski, I.; Fioramonti, L.; Sutton, P.; Farber, S.; Grasso, M. Twenty years of ecosystem services: How far have we come and how far do we still need to go? Ecosyst. Serv. 2017, 28, 1-16. [CrossRef]

3. Cheng, X.; Van Damme, S.; Li, L.; Uyttenhove, P. Evaluation of cultural ecosystem services: A review of methods. Ecosyst. Serv. 2019, 37, 100925. [CrossRef]

4. Sumarga, E.; Hein, L.; Edens, B.; Suwarno, A. Mapping monetary values of ecosystem services in support of developing ecosystem accounts. Ecosyst. Serv. 2015, 12, 71-83. [CrossRef]

5. Van Berkel, D.B.; Verburg, P.H. Spatial quantification and valuation of cultural ecosystem services in an agricultural landscape. Ecol. Indic. 2014, 37, 163-174. [CrossRef]

6. Garcia, X.; Corominas, L.; Pargament, D.; Acuña, V. Is river rehabilitation economically viable in water-scarce basins? Environ. Sci. Policy 2016, 61, 154-164. [CrossRef]

7. Kenter, J.O. Integrating deliberative monetary valuation, systems modelling and participatory mapping to assess shared values of ecosystem services. Ecosyst. Serv. 2016, 21, 291-307. [CrossRef]

8. Gandarillas, R.V.; Jiang, Y.; Irvine, K. Assessing the services of high mountain wetlands in tropical Andes: A case study of Caripe wetlands at Bolivian Altiplano. Ecosyst. Serv. 2016, 19, 51-64. [CrossRef]

9. Ungaro, F.; Häfner, K.; Zasada, I.; Piorr, A. Mapping cultural ecosystem services: Connecting visual landscape quality to cost estimations for enhanced services provision. Land Use Policy 2016, 54, 399-412. [CrossRef]

10. Unnikrishnan, H.; Nagendra, H. Privatizing the commons: Impact on ecosystem services in Bangalore's lakes. Urban Ecosyst. 2015, 18, 613-632. [CrossRef]

11. Everard, M.; Jones, L.; Watts, B. Have we neglected the societal importance of sand dunes? An ecosystem services perspective. Aquat. Conserv. Mar. Freshw. Ecosyst. 2010, 20, 476-487. [CrossRef]

12. Willemen, L.; Cottam, A.J.; Drakou, E.; Burgess, N.D. Using Social Media to Measure the Contribution of Red List Species to the Nature-Based Tourism Potential of African Protected Areas. PLoS ONE 2015, 10, e0129785. [CrossRef] [PubMed]

13. Schmidt, K.; Walz, A.; Jones, I.; Metzger, M.J. The Sociocultural Value of Upland Regions in the Vicinity of Cities in Comparison With Urban Green Spaces. Mt. Res. Dev. 2016, 36, 465-474. [CrossRef]

14. Bryce, R.; Irvine, K.N.; Church, A.; Fish, R.; Ranger, S.; Kenter, J.O. Subjective well-being indicators for large-scale assessment of cultural ecosystem services. Ecosyst. Serv. 2016, 21, 258-269. [CrossRef]

15. Bieling, C. Cultural ecosystem services as revealed through short stories from residents of the Swabian Alb (Germany). Ecosyst. Serv. 2014, 8, 207-215. [CrossRef] 
16. Ondiek, R.A.; Kitaka, N.; Oduor, S.O. Assessment of provisioning and cultural ecosystem services in natural wetlands and rice fields in Kano floodplain, Kenya. Ecosyst. Serv. 2016, 21, 166-173. [CrossRef]

17. Nahuelhual, L.; Carmona, A.; Lozada, P.; Jaramillo, A.; Aguayo, M. Mapping recreation and ecotourism as a cultural ecosystem service: An application at the local level in Southern Chile. Appl. Geogr. 2013, 40, 71-82. [CrossRef]

18. MacDonald, P.A.; Murray, G.; Patterson, M. Considering social values in the seafood sector using the Q-method. Mar. Policy 2015, 52, 68-76. [CrossRef]

19. Brown, G.; Raymond, C. The relationship between place attachment and landscape values: Toward mapping place attachment Appl. Geogr. 2007, 27, 89-111. [CrossRef]

20. Darvill, R.; Lindo, Z. Quantifying and mapping ecosystem service use across stakeholder groups: Implications for conservation with priorities for cultural values. Ecosyst. Serv. 2015, 13, 153-161. [CrossRef]

21. Brown, G.; Hausner, V.H. An empirical analysis of cultural ecosystem values in coastal landscapes. Ocean Coast. Manag. 2017, 142, 49-60. [CrossRef]

22. Hassan, R.; Scholes, R.; Ash, N. Ecosystems and Human Well-Being: Current State and Trends; Island Press: Washington, DC, USA, 2005.

23. Comberti, C.; Thornton, T.F.; Wyllie de Echeverria, V.; Patterson, T. Ecosystem services or services to ecosystems? Valuing cultivation and reciprocal relationships between humans and ecosystems. Glob. Environ. Chang. 2015, 34, 247-262. [CrossRef]

24. Sangha, K.K.; Evans, J.; Edwards, A.; Russell-Smith, J.; Fisher, R.; Yates, C.; Costanza, R. Assessing the value of ecosystem services delivered by prescribed fire management in Australian tropical savannas. Ecosyst. Serv. 2021, 51, 101343. [CrossRef]

25. Dawson, N.M.; Coolsaet, B.; Sterling, E.J.; Loveridge, R.; Gross-Camp, N.D.; Wongbusarakum, S.; Sangha, K.K.; Scherl, L.M.; Phan, H.P.; Zafra-Calvo, N.; et al. The role of Indigenous peoples and local communities in effective and equitable conservation. Ecol. Soc. 2021, 26, 19. [CrossRef]

26. Sangha, K.K.; Preece, L.; Villarreal-Rosas, J.; Kegamba, J.J.; Paudyal, K.; Warmenhoven, T.; RamaKrishnan, P.S. An ecosystem services framework to evaluate indigenous and local peoples' connections with nature. Ecosyst. Serv. 2018, 31, 111-125. [CrossRef]

27. Sangha, K.K.; Russell-Smith, J.; Costanza, R. Mainstreaming indigenous and local communities' connections with nature for policy decision-making. Glob. Ecol. Conserv. 2019, 19, e00668. [CrossRef]

28. Stoeckl, N.; Jarvis, D.; Larson, S.; Larson, A.; Grainger, D.; Corporation, E.A. Australian Indigenous insights into ecosystem services: Beyond services towards connectedness-People, place and time. Ecosyst. Serv. 2021, 50, 101341. [CrossRef]

29. Plieninger, T.; van der Horst, D.; Schleyer, C.; Bieling, C. Sustaining ecosystem services in cultural landscapes. Ecol. Soc. 2014, 19, 59. [CrossRef]

30. Pinheiro, R.O.; Triest, L.; Lopes, P.F.M. Cultural ecosystem services: Linking landscape and social attributes to ecotourism in protected areas. Ecosyst. Serv. 2021, 50, 101340. [CrossRef]

31. Bieling, C.; Plieninger, T. Recording Manifestations of Cultural Ecosystem Services in the Landscape. Landsc. Res. 2013, 38, 649-667. [CrossRef]

32. Coscieme, L. Cultural ecosystem services: The inspirational value of ecosystems in popular music. Ecosyst. Serv. 2015, 16, 121-124. [CrossRef]

33. Figueroa-Alfaro, R.W.; Tang, Z. Evaluating the aesthetic value of cultural ecosystem services by mapping geo-tagged photographs from social media data on Panoramio and Flickr. J. Environ. Plan. Manag. 2017, 60, 266-281. [CrossRef]

34. Hutcheson, W.; Hoagland, P.; Jin, D. Valuing environmental education as a cultural ecosystem service at Hudson River Park. Ecosyst. Serv. 2018, 31, 387-394. [CrossRef]

35. Hiron, M.; Pärt, T.; Siriwardena, G.M.; Whittingham, M.J. Species contributions to single biodiversity values under-estimate whole community contribution to a wider range of values to society. Sci. Rep. 2018, 8, 7004. [CrossRef]

36. Katayama, N.; Baba, Y.G. Measuring artistic inspiration drawn from ecosystems and biodiversity: A case study of old children's songs in Japan. Ecosyst. Serv. 2020, 43, 101116. [CrossRef]

37. Jiang, W.; Marggraf, R. Ecosystems in Books: Evaluating the Inspirational Service of the Weser River in Germany. Land 2021, 10, 669. [CrossRef]

38. Lansing, J.S.; Lansing, P.S.; Erazo, J.S. The Value of a River. J. Political Ecol. 1998, 5, 1-22. [CrossRef]

39. Haines-Young, R.; Potschin, M.B. Common International Classification of Ecosystem Services (CICES) V5.1 and Guidance on the Application of the Revised Structure. 2018. Available online: https:/ / cices.eu/content/uploads/sites/8/2018/01/Guidance-V5 1-01012018.pdf (accessed on 15 August 2021).

40. Below, M. Die Weser. Vom Thüringer Wald Bis Zur Nordsee; Temmen: Bremen, Germany, 2011.

41. Küster, B. Die Weser: 1800-2000; Donat: Bremen, Germany, 1999.

42. Löbe, K. Das Weserbuch. Roman Eines Flusses. 2. Aufl.; Niemeyer: Hameln, Germany, 1969.

43. Braun, H.-G.; Eckoldt, M.; Rohde, H. Die Weser. In Flüsse und Kanäle. Die Geschichte der Deutschen Wasserstrassen; Martin, E., Hans-Georg, B., Eds.; DSV-Verl.: Hamburg, Germany; Busse-Seewald: Herford, Germany, 1998.

44. Gee, K.; Burkhard, B. Cultural ecosystem services in the context of offshore wind farming: A case study from the west coast of Schleswig-Holstein. Ecol. Complex. 2010, 7, 349-358. [CrossRef]

45. Alexander, E.P. Museums in Motion. An Introduction to the History and Functions of Museums; American Association for State and Local History: Nashville, TN, USA, 1979.

46. Millennium Ecosystem Assessment. Ecosystems and Human Well-Being: Synthesis; Island Press: Washington, DC, USA, 2005. 
47. United Nations Educational, Scientific and Cultural Organization. Convention Concerning the Protection of the World Cultural and Natural Heritage. Adopted by the General Conference at Its Seventeenth Session Paris, 16 November 1972. Paris. 1972. Available online: http://whc.unesco.org/archive/convention-en.pdf (accessed on 15 August 2021).

48. Daniel, T.C.; Muhar, A.; Arnberger, A.; Aznar, O.; Boyd, J.W.; Chan, K.M.A.; Costanza, R.; Elmqvist, T.; Flint, C.G.; Gobster, P.H.; et al. Contributions of cultural services to the ecosystem services agenda. Proc. Natl. Acad. Sci. USA 2012, 109, 8812-8819. [CrossRef]

49. Allgemeiner Deutscher Fahrrad-Club. Bicycle Travel Analysis. 2016. Available online: https://www.adfc.de/fileadmin/user_ upload/Expertenbereich/Touristik_und_Hotellerie/Radreiseanalyse/Downloads/ADFC_Bicycle_Travel_Analysis_2016_ _engl._short_version_.pdf (accessed on 15 December 2021).

50. Bielefelder Verlag. Weser-Radweg: Vom Weserbergland Bis zur Nordsee. Radwanderkarte 1:75.000. 3. Aufl.; Bielefelder Verlag: Bielefeld, Germany, 2013.

51. Großmann, G.U. Renaissance im Weserraum; Dt. Kunstverl: München, Germany, 1989.

52. Paetow, K. Die Schönsten Wesersagen. 3., Durchges. und Erw. Aufl.; Sponholtz: Hameln, Germany, 1974.

53. von Dingelstedt, F. Das Wesertal von Münden bis Minden. Reprograf. Nachdr. der Ausg. Kassel und Leipzig 1838; Olms: Hildesheim, Germany, 1972.

54. Raabe, W. Der heilige Born; Vandenhoeck \& Ruprecht: Göttingen, Germany, 1968.

55. Strack, A.W.; Albrecht, T. Malerische Reise Durch das Weserbergland: Anton Wilhelm Strack, Hofmaler und Professor für Zeichenkunst in Bückeburg (1758-1829); Verl. Createam: Bückeburg, Germany, 1997.

56. Kastler, J.; Lüpkes, V. (Eds.) Die Weser. EinFluss in Europa. Aufbruch in die Neuzeit; Mitzkat (Die Weser-Einfluss in Europa, Bd. 2): Holzminden, Germany, 2000.

57. Musculus, J.C.; Eckhardt, A. Der Deichatlas des Johann Conrad Musculus von 1625/26. Faks; Holzberg: Oldenburg, Germany, 1985.

58. Stadler, K. Die Gemeindewappen der Bundesländer Niedersachsen und Schleswig-Holstein; Angelsachsen-Verl.: Bremen, Germany, 1970.

59. Veddeler, P. Wappen, Siegel, Flaggen. Die kommunalen Hoheitszeichen des Landschaftsverbandes, der Kreise, Städte und Gemeinden in Westfalen-Lippe; Ardey: Münster, Germany, 2003.

60. Hildebrandt, A.M. Handbuch der Heraldik. 19., Verb. und Erw. Aufl.; Nikol: Hamburg, Germany, 2007.

61. Taylor, B.R. The Encyclopedia of Religion and Nature; Thoemmes Continuum: London, UK, 2005.

62. Engel, A. Weserbuch. Ein erklärender Begleiter auf der Weserreise mit Berücksichtigung der Fulda von Kassel ab. Repr. d. Ausg.; Niemeyer: Hameln, Germany, 1990.

63. Hernández-Morcillo, M.; Plieninger, T.; Bieling, C. An empirical review of cultural ecosystem service indicators. Ecol. Indic. 2013, 29, 434-444. [CrossRef]

64. Ridding, L.E.; Redhead, J.W.; Oliver, T.H.; Schmucki, R.; McGinlay, J.; Graves, A.R.; Morris, J.; Bradbury, R.B.; King, H.; Bullock, J.M. The importance of landscape characteristics for the delivery of cultural ecosystem services. J. Environ. Manag. 2018, 206, 1145-1154. [CrossRef]

65. Thiele, J.; Albert, C.; Hermes, J.; von Haaren, C. Assessing and quantifying offered cultural ecosystem services of German river landscapes. Ecosyst. Serv. 2020, 42, 101080. [CrossRef]

66. Tengberg, A.; Fredholm, S.; Eliasson, I.; Knez, I.; Saltzman, K.; Wetterberg, O. Cultural ecosystem services provided by landscapes: Assessment of heritage values and identity. Ecosyst. Serv. 2012, 2, 14-26. [CrossRef]

67. Stanik, N.; Aalders, I.; Miller, D. Towards an indicator-based assessment of cultural heritage as a cultural ecosystem service-A case study of Scottish landscapes. Ecol. Indic. 2018, 95, 288-297. [CrossRef]

68. Tenerelli, P.; Demšar, U.; Luque, S. Crowdsourcing indicators for cultural ecosystem services: A geographically weighted approach for mountain landscapes. Ecol. Indic. 2016, 64, 237-248. [CrossRef]

69. van Berkel, D.B.; Tabrizian, P.; Dorning, M.A.; Smart, L.; Newcomb, D.; Mehaffey, M.; Neale, A.; Meentemeyer, R. Quantifying the visual-sensory landscape qualities that contribute to cultural ecosystem services using social media and LiDAR. Ecosyst. Serv. 2018, 31, 326-335. [CrossRef] [PubMed]

70. Wartmann, F.M.; Purves, R.S. Investigating sense of place as a cultural ecosystem service in different landscapes through the lens of language. Landsc. Urban Plan. 2018, 175, 169-183. [CrossRef]

71. Plieninger, T.; Bieling, C.; Fagerholm, N.; Byg, A.; Hartel, T.; Hurley, P.; López-Santiago, C.A.; Nagabhatla, N.; Oteros-Rozas, E.; Raymond, C.; et al. The role of cultural ecosystem services in landscape management and planning. Curr. Opin. Environ. Sustain. 2015, 14, 28-33. [CrossRef]

72. Vrbičanová, G.; Kaisová, D.; Močko, M.; Petrovič, F.; Mederly, P. Mapping Cultural Ecosystem Services Enables Better Informed Nature Protection and Landscape Management. Sustainability 2020, 12, 2138. [CrossRef] 